\title{
Brazilian energy-related climate (in)action and the challenge of deep decarbonization
}

DOI: http://dx.doi.org/10.1590/0034-7329201900202

\section{Revista Brasileira de Política Internacional ISSN 1983-3121}

http://www.scielo.br/rbpi

\section{Larissa Basso ${ }^{1}$}

${ }^{1}$ Stockholm University, Stockholm, Sweden (larissabasso@gmail.com)

\section{Copyright:}

- This is an open-access article distributed under the terms of a Creative Commons Attribution License, which permits unrestricted use, distribution, and reproduction in any medium, provided that the original author and source are credited.

- Este é um artigo publicado em acesso aberto e distribuído sob os termos da Licença de Atribuição Creative Commons, que permite uso irrestrito, distribuição e reprodução em qualquer meio, desde que o autor e a fonte originais sejam creditados.
Received: March 10, 2019

Accepted: May 13, 2019

\section{Introduction}

$\mathrm{D}$ ecarbonization has been debated since the origins of the climate regime. At first, focus was on partial decarbonization: incremental actions from industrialized countries to reduce their carbon footprint (Bataille et al. 2016). Since COP 15 (2009), limiting the long-term average temperature rise to $2^{\circ} \mathrm{C}$ compared to preindustrial levels - ideally $1.5^{\circ} \mathrm{C}$, according to the Paris Agreement (2015) - became the objective. Achieving it requires deeper transformation across electricity, transport, heating, industrial, forestry, and agricultural systems (Geels et al. 2017, 1242) to reduce global annual emissions by $42-57 \%$ by 2050 and $73-107 \%$ by 2100 , compared to 2010 levels (Sustainable Development Solutions Network and Institute for Sustainable Development and International Relations 2015). Transforming energy systems is 
key, due to global dependence on fossil fuels and the ubiquitous role of energy in current economic models.

In fact, according to the Intergovernmental Panel on Climate Change (IPCC), fossil fuel combustion and industrial processes answered for $78 \%$ of the total GHG emissions increase between 2000 and 2010 (Intergovernmental Panel on Climate Change 2014, 06). Global energy supply alone answered for $47 \%$ of the increase (Intergovernmental Panel on Climate Change 2014, 45). Emissions from the energy supply sector grew 1.7\%/year between 1990 and 2000, but 3.1\%/year between 2000 and 2010 (Intergovernmental Panel on Climate Change 2014, 516). They are expected to "almost double or even triple" by 2050, compared to 2010 numbers (Intergovernmental Panel on Climate Change 2014, 20).

This deeper transformation, or deep decarbonization, can be measured by the carbon intensity of Gross Domestic Product (GDP), or how much carbon is emitted to produce a unit of GDP. Carbon intensity of GDP can be decoupled in two. First, energy intensity of GDP, or how much energy is used to produce a unit of GDP; second, carbon intensity of Total Primary Energy Supply (TPES), or how much carbon is emitted by using one unit of energy. Although a starting point, these measurements alone (i) do not show the differences between countries nor (ii) the socioeconomic processes that drive these differences.

In this paper, we analyze the Brazilian trajectory in the context of deep decarbonization. It is divided in four sections. First, the challenge of deep decarbonization and state of play are presented. Second, Brazil is placed into this global picture, and key drivers for the outcome are identified. Third, political struggles that help explain the outcome, embedded into the political economy of the period, are analyzed. And fourth, Brazilian trajectory and future stances in the climate regime are interpreted according to the outcome.

We argue that understanding outcome and outlook in the challenge of deep decarbonization requires identifying key actors, their interests and how they interact in domestic politics (Milner 1997). Our analysis employs the causes-of-effects approach (Goertz and Mahoney 2012): by identifying the outcome, it hypothesizes its causes and tests them. It draws on primary and secondary data, including datasets from different sources and 64 semi-structured interviews, conducted between 2016 and 2017, with members of the federal administration, federal Parliament, civil society, entrepreneurs, CEOs and academics. Because the questionnaires included questions relating to politically sensitive corruption scandals involving the energy sector, we offered anonymity to our interviewees. ${ }^{1}$ The information from the interviews was merged with the information from other sources (cross-analysis of data).

\footnotetext{
1 After five pilot interviews we understood that some agents were not comfortable answering all our questions unless anonymity was offered. Therefore, and in order to guarantee the same treatment to all interviewees, we offered them anonymity first hand. We are aware that this option makes it harder to verify our findings or replicate them, but we stand by our choice, given the current political situation in Brazil. A complete list of the interviewees is available at Basso 2018.
} 


\section{The challenge of deep decarbonization: meaning and state of play}

Deep decarbonization is the structural transformation of current economic development models and lifestyles to drastically reduce carbon emissions and limit long-term global average temperature rise. It can be measured by the carbon intensity of GDP, decoupled in energy intensity of GDP and carbon intensity of TPES. Both measures are influenced by (i) energy efficiency and conservation, (ii) decarbonization of electricity and fuel production and (iii) switching to low carbon energy sources in energy end-uses (Sustainable Development Solutions Network and Institute for Sustainable Development and International Relations 2015).

Energy efficiency and conservation imply decreasing energy demand by technically improving products and processes (e.g.: improving vehicle and appliance technologies; reducing the need of artificial lighting and cooling/heating systems; optimizing logistical chains; reusing and recycling materials (Sustainable Development Solutions Network and Institute for Sustainable Development and International Relations 2015, 08). Decarbonization of electricity and fuel production and switching to low carbon energy sources in energy end-uses are most successful when fossil fuels are replaced with low carbon primary energy sources - renewables and nuclear.

When an economy decarbonizes, either or both changes are in place. Yet, energy intensity of GDP is also influenced by the economic structure. If less energy-intensive activities, e.g., services and light manufacturing energy-intensive activities, replace more intensive ones, e.g., mining, heavy industry, in total economic output, energy intensity of GDP also decreases (Fankhauser and Jotzo 2018). Thus, when reducing energy intensity of GDP is the strongest driver of decarbonization, it is key to try to understand if energy efficiency and conservation really did play a role.

According to IEA data, carbon intensity of global GDP was reduced by $20 \%$ between 2003 and 2016. Among the G20 countries $^{2}$ - together, they answer for 3/4 of all global emissions from fossil fuel combustion (International Energy Agency 2017), so their commitment with deep decarbonization is key to limit global average temperature rise - it was reduced, on average, by $25.14 \%$ in industrialized economies and by $14.99 \%$ in emerging ones. Considerable reductions took place in the United Kingdom (42.52\%), Russia (34.53\%), China (31.77\%) and the United States (31.58\%), but carbon intensity of GDP increased in Brazil and Saudi Arabia, by $2.82 \%$ and $15.79 \%$, respectively. ${ }^{3}$

\footnotetext{
2 The analysis focuses on the 19 countries members of the G20, excluding the European Union to avoid endogeneity. All calculations on this and other sections of the paper are of our own, based on the data referred.

3 On tables and figures, countries are represented by 03-digit alphabetic country codes (Alpha-3 code) from the International Standards Organization, version 3166; available at <https://www.iso.org/obp/ui/\#search>.
} 
Figure 01. Carbon intensity of economy in the G20, average, 2003-2016 (kgCO2/USD, 2005 prices - PPP)

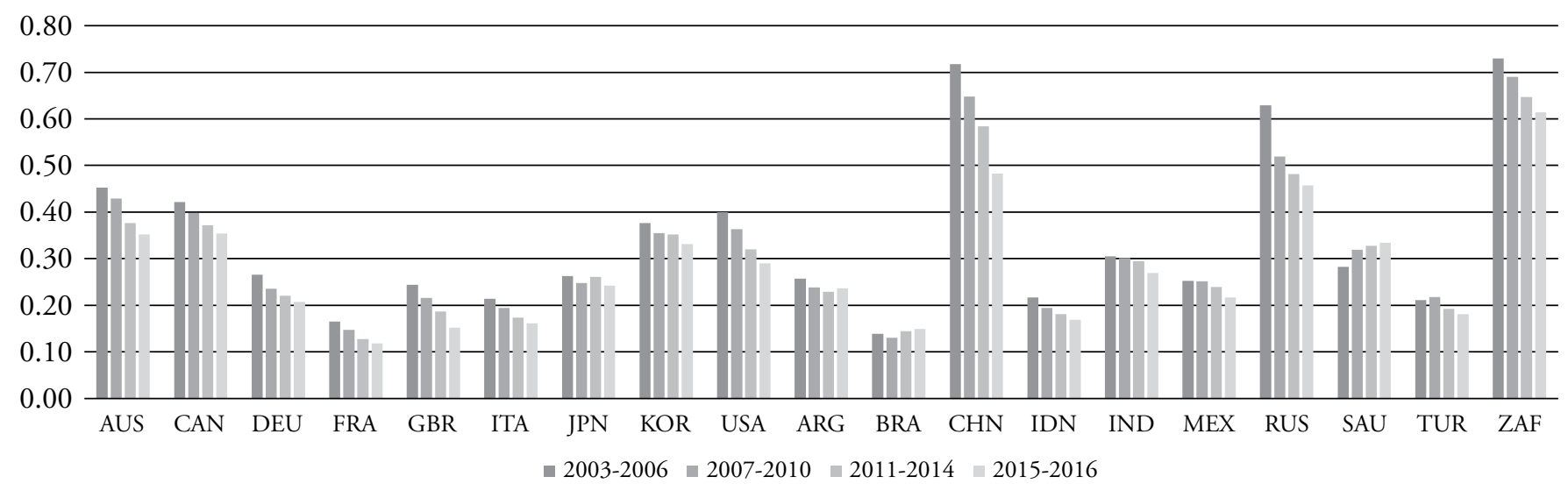

Source: Own elaboration and calculations, based on data from IEA, 2018.

Energy intensity of global GDP was also reduced between 2003 and 2016 by $20.73 \%$. Among G20's industrialized economies, it was reduced, on average, by $21.05 \%$ and among emerging ones on average by $16.76 \%$. Considerable reductions were seen in China (36.20\%), United Kingdom (34.22\%), Indonesia (30.97\%) and India (30.46\%). In Brazil and Saudi Arabia, it increased, by 3.42\% and 9.62\%, respectively (International Energy Agency 2017).

Carbon intensity of global TPES has been roughly stable, increasing by $0.85 \%$ between 2003 and 2016. It has on average decreased by 5.18\% among G20's industrialized countries and increased by $2.53 \%$ among emerging ones (International Energy Agency 2017). But while it has remained roughly stable and high in Australia, in France it was roughly half of Australia's, and it was reduced nonetheless. In Argentina and Turkey, it also remained roughly stable, but in India it has increased by $20.46 \%$ in the period.

Figure 02. Carbon intensity of energy supply in the G20, average, 2003-2016 (Mt of CO2/Mtoe)

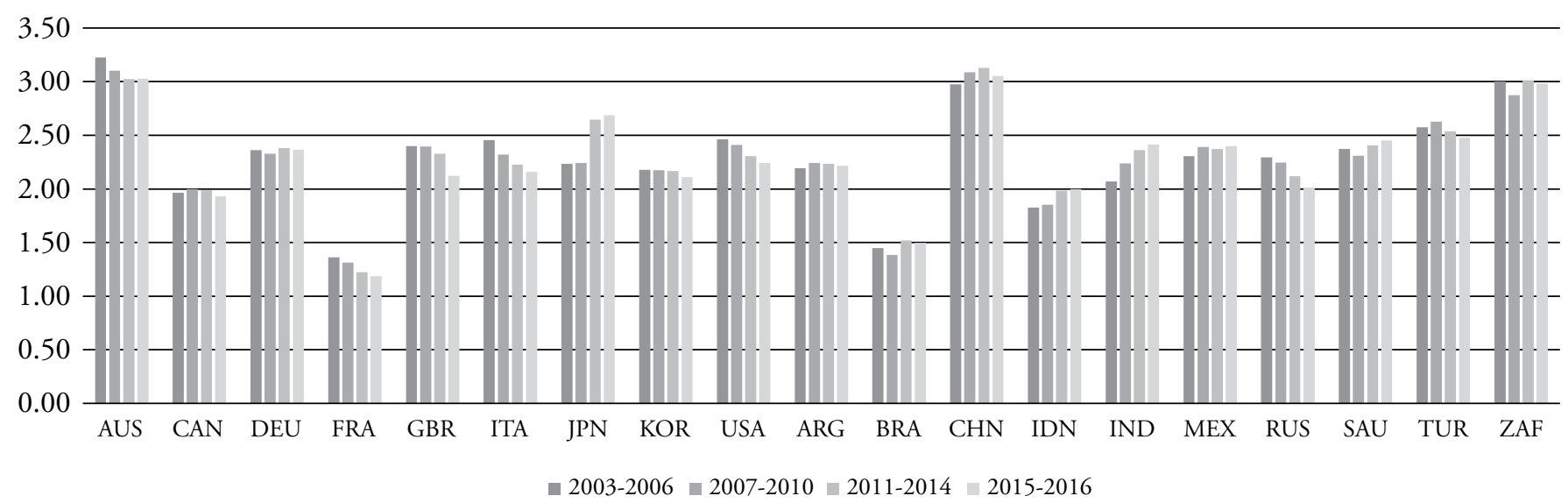

Source: Own elaboration and calculations, based on data from IEA, 2018. 
According to the data, G20 countries have been more successful in reducing the energy intensity of their GDP than the carbon intensity of their TPES. This evidence is relevant in the context of deep decarbonization. First, given that the share of energy-intensive activities - e.g., heavy industry, mining - in the G20's GDP has consistently decreased between 2003 and 2016, this structural change might have played a major role in reducing energy intensity of GDP compared to technical improvements that count for deep decarbonization.

Second, carbon intensity of TPES remains high due to global dependence on fossil fuels. Fossil fuels' (coal, oil and natural gas) share in the global TPES was $87.47 \%$ in $2003-86.83 \%$ in the G20 - and 85.18\% in 2017 - 84.46\% in the G20 ("Statistical Review of World Energy 2018, workbook." 2018). Considering that global energy supply increased 34.69\% between 2003 and 2017 (“Statistical Review of World Energy 2018, workbook.” 2018), absolute emissions from fossil fuel combustion have never been greater.

\section{Brazil in the context of deep decarbonization}

Since 1990, Land Use, Land Use Change and Forestry (LULUCF) have been the greatest drivers of Brazilian emissions. Deforestation, the main driver of Brazilian LULUCF emissions, has always been a major issue in Brazil. By the mid-2000s, Amazon deforestation was finally reduced: from an average $2.31 \mathrm{Gt}$ of $\mathrm{CO}_{2} \mathrm{e} /$ year between 2003 and 2006 to an average $0.95 \mathrm{Gt}$ of $\mathrm{CO}_{2} \mathrm{e} /$ year between 2014 and 2017 (Observatorio do Clima 2018a). Brazilian emissions decreased by 41.95\% between 2003 and 2017 because Amazon deforestation was reduced. They could have decreased more if deforestation in the Cerrado biome had been controlled - instead, it increased by $11 \%$ in 2017 alone (Observatorio do Clima 2018b).

Figure 03. Trajectory of Brazilian CO2 emissions, GWP-AR5, 2003-2017

(Gt of $\mathrm{CO} 2 \mathrm{e})$

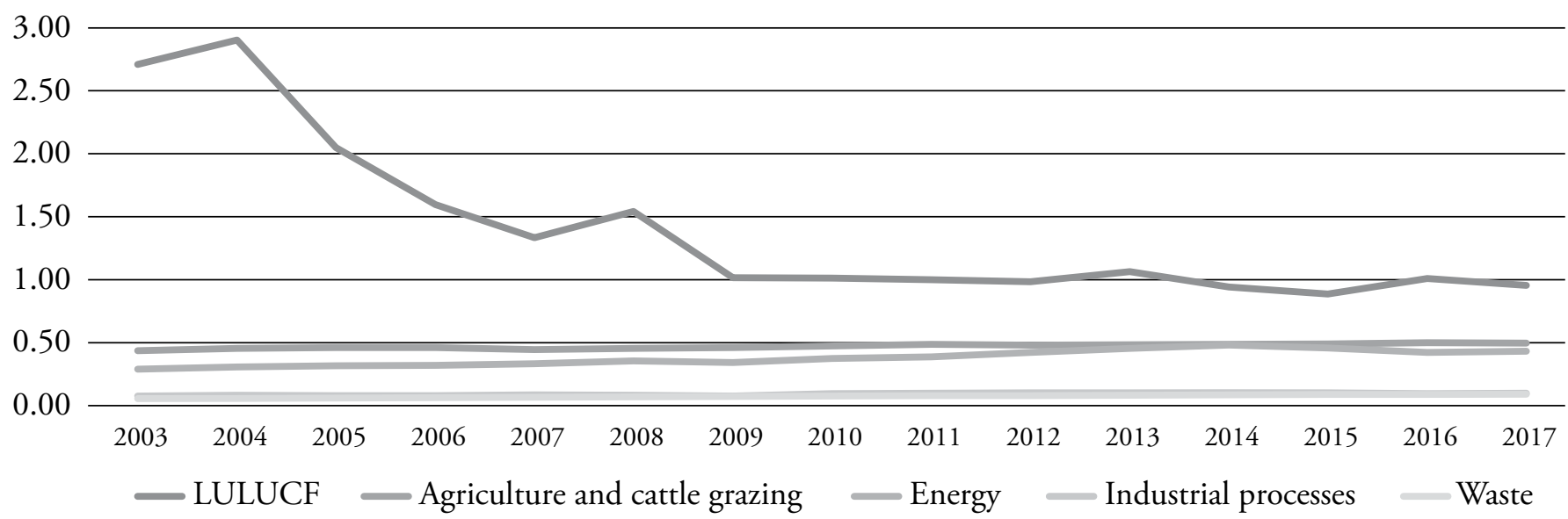

Source: Own elaboration and calculations, based on data from OC, 2018a 
GHG emissions from all other sectors have increased in Brazil between 2003 and 2017: by $13.55 \%$ in agriculture/livestock; by $29.30 \%$ in industrial processes; by $48.70 \%$ in energy; and by $62.60 \%$ in waste (Observatorio do Clima 2018a). After deforestation rates were reduced, agriculture/livestock emissions and energy emissions became more relevant in total Brazilian emissions. While LULUCF emissions' share remain dominant $-71.16 \%$ of total Brazilian emissions between 2003 and 2006, and 45.87\% between 2015 and 2017 -, agriculture/livestock and energy shares increased from $14.48 \%$ and $9.89 \%$ to an average $23.92 \%$ and $21.13 \%$, respectively (Observatorio do Clima 2018a).

Compared to the global average or to that of G20 peers, the Brazilian energy matrix has higher participation of low carbon sources. While the fossil fuels' share in G20's average energy matrix was 86.51\% between 2003 and 2006, and 84.62\% between 2015 and 2017, it averaged 61.14\% and 64\% in Brazil, respectively ("Statistical Review of World Energy 2018, workbook." 2018). Between 2003 and 2017, oil and hydropower's shares in the Brazilian energy matrix decreased, from an average 39\% and $14.72 \%$ between 2003 and 2006 to an average $36.68 \%$ and $11.93 \%$ between 2015 and 2017, respectively (Empresa de Pesquisa Energética 2018). In the same periods, natural gas and sugarcane products' shares increased, from an average $8.96 \%$ and $13.88 \%$, to an average $12.99 \%$ and $17.25 \%$, respectively (Empresa de Pesquisa Energética 2018). Coal's share was small and decreased slightly, as well as firewood and charcoal's; other renewables, including wind and solar energy, still have a very small participation in the matrix (Empresa de Pesquisa Energética 2018).

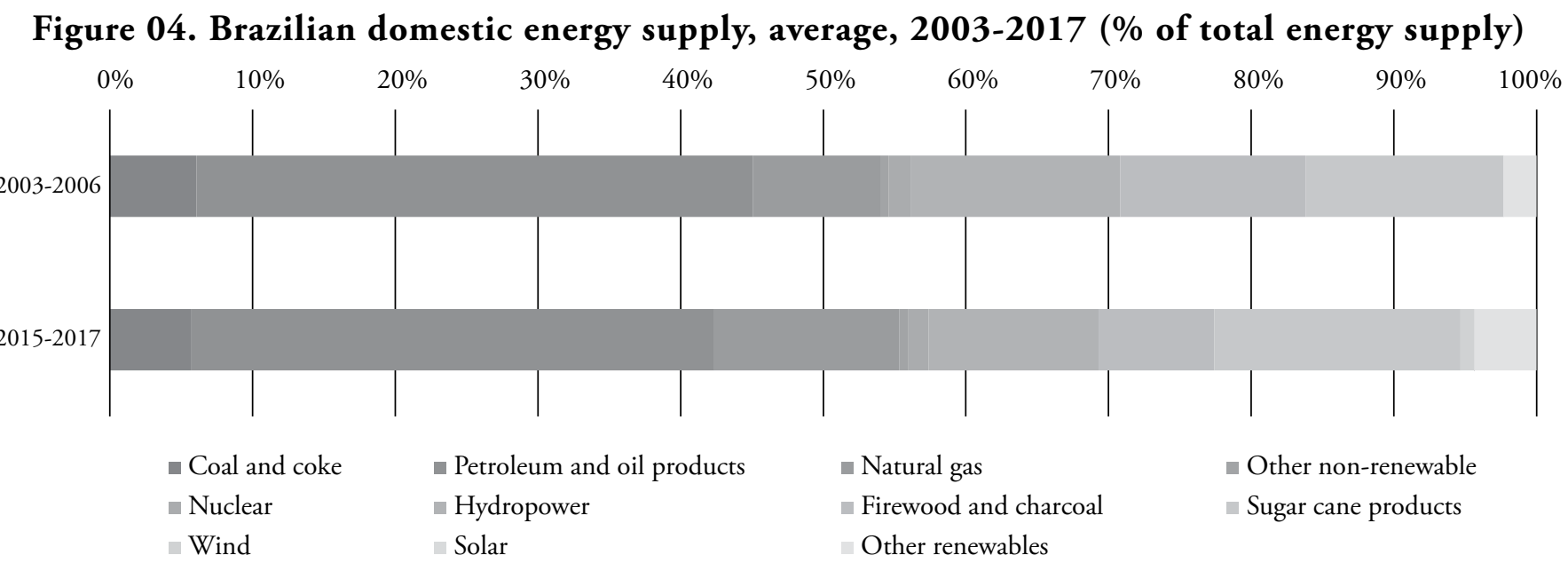

Source: Own calculations and elaboration, based on data from EPE, 2018.

Brazil is the world's $7^{\text {th }}$ largest energy consumer (International Energy Agency 2017). Between 2003 and 2017, energy consumption in Brazil increased by 42.46\%. The economic sectors' participation in total energy consumption has changed in the period. The energy and transportation sectors' shares increased from an average $8.92 \%$ and $26.79 \%$ between 2003 and 2006 to $10.33 \%$ 
and 32.40\% between 2015 and 2017, respectively (Empresa de Pesquisa Energética 2018). The industrial sector's share, however, decreased from an average $37.39 \%$ to $32.82 \%$ in the same intervals (Empresa de Pesquisa Energética 2018).

The data presented above can be summarized in the following trends. First, total Brazilian emissions have decreased between 2003 and 2017 due to control of Amazon deforestation. However, emissions from all other economic sectors - as well as from deforestation in other biomes - have been increasing. Second, as LULUCF emissions decreased, emissions from other sectors, especially agriculture/livestock and energy, became relatively more relevant in Brazil. Third, energy-related emissions are rising faster than agriculture/livestock's. Fourth, although Brazil has a higher share of low carbon sources in its energy matrix compared to global average and peer countries, this share has been decreasing.

Last, but not least, both energy consumption and energy intensity of GDP have increased in Brazil between 2003 and 2017. Energy consumption rises when access to energy services, as well as household appliances and vehicles expand, as is the case in Brazil between mid-1990s and 2014. Yet, energy intensity of GDP increased while activities with higher added value contributed less to GDP: between 2003 and 2017, agriculture, forestry and fishing's added value to Brazilian GDP decreased by 25.98\%; industry's, by $19.96 \%$ ("Indicators: Agriculture, Forestry and Fishing's value added, \% of GDP; Industry's value added, \% of GDP.” 2018). Thus, Brazilian rising energy intensity of GDP is driven both by consumption and production, with decreasing added value.

\section{Brazilian energy politics, 2003-2017}

\section{Hydro has it its way, but gas-fired thermoelectric generation is boosted instead}

During the Cardoso administrations, a new model - in which private investors would replace the federal government as the main agents, and competition and efficiency would be awarded - was envisaged for the energy sector. This was in tandem with the ongoing transformation of energy sectors in several countries and with lack of public resources to invest in new generating capacity (Victor and Heller 2007), as well as with ongoing transformations of the Brazilian economy. However, electricity incumbents and the electric bureaucracy opposed it. They argued that Brazil was a hydropower country and a hydro-dominated electricity system was less efficient under full competition. In the electric sector, state-owned hydropower actors had always played a key role, including in providing professional cadres for the electric bureaucracy, and their influence remained even after partial privatization of the sector.

The Lula da Silva administration halted the implementation of the model in the energy sector and steered it towards recentralization. Privatizations, a hallmark of the previous administrations, 
were no longer pursued, and the role of the remaining state-owned energy utilities was strengthened. The administration focused in (i) re-establishing long-term planning and policy guidance for the electric sector (Oliveira 2007, 58) and (ii) reducing systemic risk for electricity generation, a key issue after the 2001/2002 Power Supply Crisis. ${ }^{4}$

Ten-year plans were established. Planning was based on three principles: security of supply, affordability of tariffs and universal access to power services (Empresa de Pesquisa Energética 2015, 389). Only dispatchable electricity plants - large hydropower plants with reservoirs and thermoelectric plants, the ones in which electricity generation can be switched on or off according to the demand, not subject to natural intermittence - are understood to provide security of supply. Affordability of tariffs is understood to be maximized by economies of scale, so large-scale electricity generating facilities are preferred (Schaeffer et al. 2015, 30). Thus, planning - and auctions - started to prioritize large-scale hydropower plants and thermoelectric plants were established as a backup system. Other sources were given only a complementary role to the grid.

At first, increasing demand was indeed met by hydropower. One, there was idle capacity in large hydropower plants, due to a $20 \%$ reduction of electricity demand achieved in the context of the 2001/2002 Power Supply Crisis. Two, reservoirs, depleted at the time of the Crisis, were once again full due to normalized rainfall patterns. However, electricity demand was increasing fast: the Brazilian economy was growing around $4 \%$ per year at the time, pulled by the Chinese appetite for agricultural and mineral commodities. Thus, plans to build large new hydropower plants in the Amazon region, where most of the remaining Brazilian hydropower potential is, were resumed. ${ }^{5}$ Yet environmental NGOs in the Amazon region, the Movimento dos Afetados por Barragens, MAB (Movement of People Affected by Dams) and civil organizations defending the rights of indigenous people opposed them. As a compromise, the run-of-the-river technology was implemented instead.

In run-of-the-river hydropower plants, instead of a large dam - which stores large amounts of water to guarantee a steady flow through the turbines and constant electricity outputs - smaller dams are built, so electricity production is affected by hydrological variation. If run-of-the-river plants are built where hydrological flows vary substantially over the seasons - the case of Amazonian rivers-, security of supply is affected, so backup systems will be activated. And if dispatchability is a necessary requirement for a backup system, then fossil fuel-fired, especially gas, thermoelectric plants will play this role. ${ }^{6}$ Thus, more and more gas-fired thermoelectric plants were built and switched on in Brazil.

\footnotetext{
4 In 2001, several cuts in electricity provision took place throughout Brazil. The immediate cause of the crisis was the depletion of hydropower reservoirs during years of lower rainfall outputs, but there are different views about the fundamental cause. Some argued that delays of privatizations and changes made to adapt the system to powerful hydropower's interests postponed much needed investments in expanding electricity generation. Others argue that the new model was never feasible in a hydro-dominated country such as Brazil, and the federal government was responsible for the crisis for trying to implement it. To solve the crisis, throughout 2001-2002 a compulsory reduction in electricity consumption was imposed to all consumers. The crisis took place in a moment in which the Brazilian economy was growing fast, so the impact was very relevant.

5 Plans for most of the hydropower plants in the region exist since the 1980s, when the military were in power in Brazil.

6 Renewable biomass such as sugarcane can in theory be stored as well, but in practice it is not, as producers choose to adjust the production of other sugarcane (sugar, ethanol) products instead of keeping stocks.
} 
The role of gas-fired thermoelectric plants in electricity generation has increased even more after the Rousseff administration intervened in the electric sector in 2012. In trying to boost industrial production growth by artificially reducing electricity prices for industrial consumers, Rousseff changed the rules for remuneration and renovation of concessions for electricity utilities, expecting that most would accept them. ${ }^{7}$ Yet, most did not, and rainfall patterns were also lower than expected that year, so the hydropower reservoirs' capacity was again depleted. As a result, and in order to avoid another power supply crisis, more gas-fired thermoelectric power plants were switched on, at much higher costs for consumers and the environment.

\section{Brazil, an ethanol global powerhouse... until deep offshore oil is discovered}

The period between 2003 and 2006 was one of the most favorable to the ethanol industry in recent history. The sector had invested heavily in $\mathrm{R} \& \mathrm{D}$ and technology in previous years, so productivity had risen - from 3900 liters/hectare/year in 1980 to 5600 liters/hectare/year in 2001 (Hira and Oliveira 2009, 2454). Verticalization had reduced costs and enhanced scale. Flex-fuel vehicles and higher prices of oil products were sustaining the high consumption of ethanol in Brazil. Brazilian ethanol was also exporting more. ${ }^{8}$ The Lula da Silva administration understood that ethanol could be a key diplomatic tool to promote Brazilian leadership in the international system, and launched what was later called the ethanol diplomacy.

The ethanol diplomacy was a diplomatic strategy to position Brazil as a leader in international energy debates and enhance Brazilian soft power (Machado 2014). Between 2006 and 2008, Brazil launched different multilateral and bilateral initiatives regarding biofuels. Memorandums of Understanding on biofuels were signed in the India-Brazil-South Africa Dialogue Forum, and between Brazil and the West African Economic and Monetary Union; a working group on the topic was created in MERCOSUR; bilateral cooperation agreements were signed with Benin, Burkina-Faso, Ghana, Mozambique, Kenya, Rwanda, Ethiopia, Senegal, Nigeria, Guinea-Bissau, Algeria and South Africa; partnerships were established with the United States, the European Union, Sweden, China and Japan (Machado 2014). EMBRAPA - the Brazilian state-owned company leader in agriculture R\&D - opened two offices in Africa. In 2008, the International

\footnotetext{
Provisional Measure nr 579, from 11 Sep 2012, later converted into Federal Law nr 12783, from 11 Jan 2013. According to it, the federal government would grant a $20 \%$ reduction in the final price of electricity to industrial consumers by (i) exempting the sector from paying some levies; (ii) anticipating the renewal of generation and transmission concessions whose contracts would end starting in 2015; (iii) resources from the Federal Treasury to restore financial capacity in the sector.

8 E.g., to California, where there is a mandate to reduce emissions from fuels, and sugarcane's ethanol is classified as advanced compared to corn's: its lifecycle emissions are $50 \%$ lower than gasoline's, while corn's are $30 \%$ lower.
} 
Conference on Biofuels was held in São Paulo. The strategy did project Brazilian expertise in the field, but it did not create an international market for biofuels. ${ }^{9}$

Whether or not by coincidence, by the time the deep offshore oil reserves were discovered in Brazil, the ethanol diplomacy started to fade. In 2007, PETROBRAS announced that oil had been found under salt layers of the Brazilian continental platform. At the time, international oil prices were rising - it averaged USD 80 per barrel in 2007 and would hit more than USD 100 per barrel in 2008 ("Statistical Review of World Energy 2018, workbook." 2018). Soon, the federal government was announcing that Brazil would become a major oil exporter. The revenues were expected to cover rising public spending, which rose consistently throughout da Silva's administrations, and was no longer funded by commodities exports, since the Chinese appetite had decreased, and international prices followed.

By the time Rousseff took office, the Brazilian economy was going through rough times. Economic activity was slowing down, and inflation was rising. In trying to boost economic growth and control inflation, the federal government intervened to keep prices of domestic oil products artificially lower than the international ones. PETROBRAS was forced to sell oil products in the domestic market for a lower price than what the company paid to import them. In addition, the rate of CIDE combustiveis - the tax that needs to be paid when fuel is imported or commercialized - was reduced ${ }^{10}$ until full exemption was granted between 2012 and 2014. Thus, between 2011 and 2014, oil prices were subsidized by the federal government in Brazil (Costa and Burnquist 2016).

The consequences of the subsidies were dire. PETROBRAS had to absorb huge losses, and by the time the deep offshore oil auctions started in 2013, it had no financial capacity to invest and keep up with partnerships, as required by law. ${ }^{11}$ The ethanol industry was penalized. Tax exemptions for the purchase of industrialized products such as residential appliances and automobiles were also offered by the federal government at the time, so Brazilian light-vehicle fleet - most of it flex-fuel - increased. However, because gasoline's relative prices were lower than ethanol's, consumers would opt for the first to fill their cars. In sum: (i) ethanol did not become an international commodity, and Brazilian ethanol industry suffered important losses; (ii) Brazil did not become a major oil exporter. In addition, it might not be economically feasible to extract all deep offshore oil from the ground, depending on international oil prices.

\footnotetext{
9 In the United States, Brazilian sugarcane ethanol competes with locally produced corn ethanol, and lobby to protect national producers is very strong. In Europe, the oil industry, the food industry, part of the automobile industry, local producers of ethanol - from beet juice, wheat, agriculture residues - and some NGOs lobby against Brazilian ethanol. They argue that ethanol production increases deforestation in the Amazon region, reduces output of crops used for food and is not sustainable. None of the arguments is true. Sugarcane plantations are relatively small compared to areas used to grow food, and they are concentrated in the Southeast and Northeast regions of Brazil, very far from the Amazon. Sustainability criteria have become very stringent for the sugarcane industry lately, especially in the largest producing region, Sáo Paulo, where regulation has improved and investment in new techniques and technologies has been made to respect it.

10 CIDE over gasoline started to be reduced in 2008.

11 The price of its shares collapsed; minority shareholders started lawsuits in the United States, where PETROBRAS shares are also listed; corruption scandals that followed would increase the amount of class actions and threaten the company's viability.
} 


\section{Where are wind and solar in the Brazilian electricity matrix?}

Despite a considerable potential to generate electricity from wind and solar, these primary sources still hold a very small share in the Brazilian energy matrix. In 2003, wind and solar participation in total electricity generation was insignificant (0.02\%), and in 2017 it was $7.35 \%$ (Empresa de Pesquisa Energética 2018). Brazil is a laggard in adding these sources to its electricity matrix, even compared to other emerging economies, and the reason lies, again, in the trajectory of the political economy of energy in Brazil.

Wind energy was first targeted as a primary electricity source in the context of the 2001/2002 Power Supply Crisis, when the Programa de Incentivo às Fontes Alternativas de Energia Elétrica, PROINFA (Incentives to Alternative Electric Sources) ${ }^{12}$ was enacted. PROINFA was divided in two phases. In the first, 3,300 MW of installed capacity provided equally by wind, renewable biomass and small-scale hydropower plants were to be added to the Brazilian electric matrix until 2008. Incentives offered to investors included: BNDES would finance the projects, but at least $60 \%{ }^{13}$ of the technology employed should be produced in Brazil; ELETROBRAS would purchase their produced electricity in public calls offering 20-year contracts that would pay a higher price for electricity output compared to large hydropower and thermal power plants (Dutra and Szklo 2006). In the second phase of PROINFA, the three technologies combined would provide, in 20 years, at least $10 \%$ of total electricity consumed annually in Brazil.

The combination of reserve auctions, subsidized finance from BNDES and market production encouraged the development of a local wind industry, which involves heavy, low-technology components that can be produced in Brazil (Hochstetler and Kotska 2015, 82-83). However, wind energy also benefited from the economic circumstances of the time. The industry had expanded especially in Europe, but when the international financial crisis hit, new markets were explored. On top of the subsidies and the regulatory changes Brazil had implemented in the electric sector, the Brazilian economy was stable and growing at the time, so Brazil became a very attractive market for wind power companies.

By the late 2000s/early 2010s, wind stakeholders lobbied to bid against hydro and thermal power plants in main electricity auctions. Given lowering wind prices offered in complementary auctions, ANEEL authorized it. Wind proved competitive against thermal power plants, and its participation in Brazilian electricity generation has increased: in 2017, it produced $7.21 \%$ of total electricity supply (Empresa de Pesquisa Energética 2018).

Wind stakeholders argue that a hydro-wind electric system could replace the hydro-thermal system currently in place, due to complementary hydrological and wind cycles in Brazil. This position has the support of environmentalists, part of the Academia, some labor organizations and state governments in which wind energy potential is high. But long-term electric technicians

\footnotetext{
12 In July 2001, Programa Emergencial de Energia Eólica, PRO-EÓLICA (Emergency Program for Wind Energy), aiming to add 1050 MW of installed capacity of wind energy to the grid by December 2003, was enacted, but it never entered into force.

13 In the second phase, $90 \%$.
} 
and actors aligned with the fossil fuels oppose it. They argue that supply security becomes too complex when intermittent primary sources are added to the grid, and only cost-competitive storage technologies, not available to date, could change this picture (Basso 2018). The federal government's position is in line with the latter; it accepts a future hydro-thermal-wind electric system in Brazil (Empresa de Pesquisa Energética 2015, 91), but thermal power remains Brazil's main backup system.

Solar was not included in PROINFA because it was considered too expensive. It is more expensive than other technologies, but the fact that the solar industry is technology-intensive and there was no capacity to develop a solar national industry at the time played a big role (Hochstetler and Kotska 2015). Solar photovoltaic technology was authorized to bid for the first time in 2014, in restricted auctions. In 2016, the federal government announced measures to promote the development of national solar industry: more auctions in which solar could bid; credit lines with low interest rates to solar power plants that would purchase solar panels made in Brazil; tax exemption to purchase components employed in making the panels. However, it did not follow through: the participation of solar was cancelled in bids that took place in 2016, and in 2017 there was an auction to terminate several agreements signed in previous bids; credit lines with even lower interest rates were offered to solar power plants operating with imported panels; and the promised tax exemption was not enacted to date.

It is claimed that solar energy is more competitive in distributed generation and, by expanding it, Brazilian 2024's electricity demand in Brazil could be reduced by $12.64 \%$ (Empresa de Pesquisa Energética 2015, 382). Yet, there are barriers for the expansion of distributed generation in Brazil.

First, distributed generation requires smart grids - which allow electricity from the grid to enter the building but also electricity produced by solar panels in the building to enter the grid - and they are still the exception in Brazil. Second, financing options for small scale projects are lacking. Interest rates are very high in Brazil, and despite the low-risk nature of the investment in distributed generation, banks offer no special funding lines for it, preventing many potential prosumers to adopt the technology. Finally, maintenance is still a barrier. In Brazil, few companies offer specialized maintenance of solar panels, so the service is still quite expensive; the lack of a national solar industry adds to the challenge. The grids themselves require better maintenance to reduce transmission losses, otherwise these could offset gains from distributed generation (Basso 2018).

\section{Energy conservation, the elephant in the room}

In Brazil, energy efficiency and conservation have been largely neglected. Although some initiatives started earlier, ${ }^{14}$ energy efficiency became a hot topic in the context of the 2001/2002 Power Supply Crisis. At the time, a national policy for energy conservation was

14 National Electrical Energy Conservation Program (in Portuguese, PROCEL), enacted in 1991 and implemented for residential appliances and lighting since 1993; the Rational Use of Oil and Natural Gas By-products Program (in Portuguese, CONPET), implemented in 1991. 
enacted $^{15}$ and several initiatives to reduce energy use either entered into force or were revisited, ${ }^{16}$ but soon after, when the Crisis was overcome, the topic was dismissed.

Energy conservation could play a significant role in Brazil, ${ }^{17}$ but there are barriers. First, effective policies require multi-sectoral coordination between authorities at different jurisdictions - federal, state and municipal authorities. They divide competence to legislate topics of relevance to energy efficiency and conservation, e.g.: building codes are enacted by municipalities; states are the ones entitled to tax property of vehicles; the Brazilian electricity grid is national, but taxes over circulation of goods and services are also in the states' jurisdiction. Yet multi-level coordination, in different issues, is still underdeveloped in the Brazilian public administration. ${ }^{18}$

Second, policies directed at tackling other issues interfere with energy efficiency. The flex-fuel technology was developed to boost the consumption of ethanol in the 2000s, after the ethanol supply crisis of the 1990s. ${ }^{19}$ Although it answers to sugarcane's and automotive industries' interests, it allows consumers flexibility when filling up their car's tanks, reduces air pollution and GHG emissions, engines built to function on both gasoline and ethanol are less efficient than vehicles built to function on only one of them (Costa 2017, 131-132).

Third, structural issues need to be addressed. Brazilian electricity transmission lines are very long and poorly maintained, so significant output is lost in transmission (Viola and Basso 2016, 824). There is little integration between research institutes and industrial activities in Brazil, which reduces opportunity to develop better practices and technologies adapted to national circumstances (Costa 2017, 136). Transport infrastructure, especially for freight, is also highly inefficient in Brazil.

Finally, energy efficient labeling is rarely considered by consumers. Although the 2001/2002 Power Supply Crisis has raised awareness towards labeling in residential appliances and lighting, many consumers still overlook it in favor of other short-term criteria (e.g., the price of the good itself). In case of other goods, such as vehicles, most consumers ignore the labeling of the vehicle they are purchasing (Costa 2017, 134).

\footnotetext{
15 Federal Law nr 10295, from 17 Oct 2001 and Federal Decree 4059, from 19 Dec 2001.

16 E.g., Programa Brasileiro de Etiquetagem (National Labeling Program), in versions for public lighting, buildings, industry and vehicles; Inovar Auto, incentives for innovation and energy efficiency in vehicles, in force between 2012 and 2017, and followed by Rota 2030, in force since 2018.

17 The federal government's calculations show that 2024's projected energy demand could be reduced by $4.7 \%$ and projected electricity demand could be reduced by 5.3\% if energy conservation measures were implemented (Empresa de Pesquisa Energética 2015, 373-374), and these numbers project only marginal gains from replacing technologies and appliances for more energy efficient ones (Empresa de Pesquisa Energética 2015, 375-381), not structural changes that could have greater impact.

18 Lack of monitoring also plays a role: according to the Federal Law nr 9991, from 24 Jul 2000, electricity utilities are required to invest a share of their liquid revenues in R\&D and energy efficiency measures, but although they must report the amount spent, they are not required to specify in which measures it was spent.

19 At the time of the crisis, international sugar prices were rising, so producers would prefer to sell sugar to ethanol. However, many consumers had purchased ethanol-only vehicles due to government incentives during the Pro-Alcohol Program; ethanol prices escalated, and a supply crisis took place. In the 2000s, when there was interest to increase the use of ethanol again, consumers would not purchase ethanol-only vehicles, so the flex-fuel technology was developed instead.
} 


\section{Brazil, a conservative climate power}

Since the climate regime emerged, Brazil has mostly been a conservative climate power (Viola et al. 2013), although for a brief period it progressed to a moderately conservative position. Unfortunately, the transition to a moderate conservatism was circumstantial, not structural, and there is no evidence that Brazil could become more reformist in the near future.

Brazilian stances in the climate regime in the 1990s and 2000s echoed domestic resistance to make Brazil internationally liable for deforestation in the Amazon (Viola 2004, 40; Hochstetler and Viola 2012, 761). In the 1990s, there were two main drivers of deforestation. First, while further opening the Brazilian economy to globalization and private capital, the Cardoso administration also encouraged investment in mining, energy production and soybean plantation - activities with great impact in deforestation. Second, illegal deforestation was high, and there was low institutional capacity to fight it, including very weak surveillance technology - a radar system only became operational in 2002 (Viola 2004, 39). At first, Brazil embraced climate change as a relevant issue but argued the role of industrialized countries to tackle it. Later, it would support the Kyoto Protocol as long as it would not impose binding commitment for developing countries, arguing common but differentiated responsibility, and commitments would not involve forests. When the Clean Development Mechanism (CDM) was approved, Brazil would accept that reforestation and forestation would count as carbon sink activities, but not avoided deforestation (Viola 2004, 41).

Climate change was a marginal issue in the early years of the first Lula da Silva administration. Yet, Marina Silva, a long-term and internationally respected environmentalist, was chosen to be Minister of the Environment (2003-2008). She implemented bureaucratic changes, created cooperation strategies between state governors in the Amazon region and the federal government, and monitored regulatory changes and their enforcement, substantially improving forest governance (Hochstetler 2017, 266-267; Hochstetler and Viola 2012, 761; Viola and Franchini 2018). ${ }^{20}$

Under new forest governance strategy, the position of most governors and several mayors in Amazonian states regarding deforestation changed. If earlier they opposed any commitment with reducing deforestation, now the opportunity to receive CDM funds to undertake forest conservation reverted their stances (Hochstetler and Viola 2012, 762; Viola and Franchini 2018). In addition, Amazonian landowners and agribusiness also joined the club, answering to pressure from importing markets that started boycotting products from deforested areas. ${ }^{21}$

\footnotetext{
20 Change in the Forest Code - enacted in 1996 but implemented since 2006 - increased the minimum area to be protected by landowners in the Amazon region to $80 \%$. In 2006, a new law allowed the Union to transfer areas of its property to private agents that could manage it sustainably and established the Brazilian Forest Service to oversee activities in forested areas. New national parks and conservation units were created, and law enforcement became more effective: the number of law enforcement operations to deter illegal logging and fines levied for violation of forestry regulations reached a record high (Hochstetler and Viola 2012; Viola and Franchini 2012; Viola 2013). Amazon deforestation rates started to decrease: $27,800 \mathrm{~km}^{2}$ in $2004 ; 19,000 \mathrm{~km}^{2}$ in $2005 ; 7,500 \mathrm{~km}^{2}$ in 2009 (Instituto Nacional de Pesquisas Espaciais n. d.).

21 Transnational environmental networks had started to trace illegal logging and campaigned against their sales in industrialized countries with success. Large importers of Brazilian soybeans and beef established moratoriums: they would not purchase crops or beef produced in deforested areas (Hochstetler and Keck 2007; Hochstetler and Viola 2012; Viola 2013).
} 
Businesses' positions also changed, motivated by the Waxman-Markey Act approved at the United States' House of Representatives. ${ }^{22}$ Three corporate alliances emerged around mid-2009: (i) Aliança de Empresas Brasileiras pelo Clima (Brazilian Business Climate Alliance), pressuring the government to reduce deforestation in the Amazon region and to accept market mechanisms for avoided deforestation (Viola 2010, 102; Kasa 2013, 1058); (ii) Carta Aberta ao Brasil sobre Mudanças Climáticas (Open letter to Brazil about Climate Change), requesting the government to make a formal commitment to reduce emissions and adopt the policy to consistently reduce the curve of emissions growth (Viola 2010, 102; Kasa 2013, 1058); and (iii) Coalizão de Empresas pelo Clima (Corporate Coalition for Climate), pressuring the federal government to undertake mandatory emissions reductions by 2020 compared with the 2007 baseline (Viola 2010, 103).

Finally, the public opinion's knowledge and support for climate action increased at the time. Extreme weather events and intense coverage of the media over climate topics raised the public opinion's awareness (Held et al. 2012, 68-69). After Marina Silva left Lula da Silva's administration in 2008 and became a candidate in the 2010 Presidential elections, the climate topic was included in the campaign. Other candidates were forced to acknowledge it, including the candidate supported by Lula da Silva, Rousseff, accelerating change in the Brazilian position in the climate regime (Hochstetler and Viola 2012, 763-764; Viola et al. 2013, 295-296; Viola and Franchini 2018).

In 2009, at COP15, Brazil pledged to reducing $36.1 \%$ to $38.9 \%$ of its curve of emissions growth projected for 2020, later incorporating it to the National Climate Change Policy. ${ }^{23}$ Despite this more moderate standing compared to previous ones - considering earlier reluctance to accept emission reduction targets -, it was still very poor, as the baseline was an inflated business-as-usual emissions scenario (Basso and Viola 2017, 182). In essence, Brazil was simply saying to an international audience that it was going to do what it had already started to do (Hochstetler and Viola 2012, 768; Viola and Franchini 2018).

Since 2011, and more clearly since 2014, Brazil resumed its conservative profile. With lower rates of deforestation in the Amazon, ${ }^{24}$ energy and agriculture/livestock emissions became more relevant in total amount, so coalitions needed to support stronger climate stances became more complex and more difficult to be formed (Basso and Viola 2017, 182). In addition, amidst economic crisis, unemployment, rising inequality and massive corruption scandals, Brazilian public opinion became less attentive to environmental topics in general and climate change in particular (Viola and Franchini 2018).

\footnotetext{
22 The act (later rejected at the US Senate) would impose border taxes for imports from countries without climate commitments. Corporations started worrying about their competitiveness in the international market (Hochstetler and Viola 2012, 762-763).

23 Law nr 12187, from 29 Dec 2009.

24 Although LULUCF emissions remain the most relevant in total Brazilian emissions, as seen in section "Brazil in the context of deep decarbonization," above.
} 
The Brazilian NDC illustrates this return to conservatism. Brazil pledged to reduce GHG emissions by 37\% below 2005 levels by 2025 and 43\% below 2005 levels by 2030, although it does indicate a baseline: 2005 is the year in which deforestation peaked in Brazil, thus a very poor one. Besides, pledges for specific sectors lack ambition.

Regarding LULUCF emissions, Brazil pledged to strengthen and enforce the implementation of the Forest Code. Yet, the Forest Code was changed in 2012 to allow the area protected from deforestation to be reduced, basically authorizing more deforestation. Brazil also pledged to zero illegal deforestation only by 2030, which means that for more than a decade deforestation rates could remain high as they are now. The pledges to restore and reforest 12 million hectares of forests by 2030 and to enhance sustainable native forest management systems are welcomed. Yet, given recent setbacks in controlling deforestation, it is still very difficult to see how these new targets will be enforced.

In the agriculture/livestock sector, Brazil pledged to strengthen the Programa Agricultura de Baixo Carbono, Programa ABC (Low Carbon Emissions Agriculture Program), to restore 15 million hectares of degraded pasturelands and to enhance integrated crop-livestock-forestry systems in 05 million hectares, all by 2030. The objectives are positive, but almost irrelevant. First, finance opportunities and subsidies for conventional agriculture - which, in Brazil, employs very high rates of fertilizers, affecting the global cycle of nitrogen, and record rates of pesticides - are expressively higher than the ones destined to Programa ABC. Second, Brazil has around 172.3 million hectares of pasturelands (Dias-Filho 2014, 12); 50\% of it is severely degraded and 25\% moderately degraded, so around 129.2 million hectares are degraded (Dias-Filho 2014, 24). Thus, the INDC target of restoring 15 million hectares is very, very shy.

In the energy sector, Brazil pledged, by 2030, (i) to increase the share of sustainable biofuels in the energy mix to approximately $18 \%$, but their participation has been higher than 18\% - in 2016, they were 19.9\% (Ministério de Minas e Energia 2017, 26); (ii) to achieve $45 \%$ of renewables in the energy mix, but they answered for 43.5\% in 2016 (Ministério de Minas e Energia 2017, 21); (iii) to expand the use of renewables other than hydropower in the total energy mix to between $28 \%$ to $33 \%$, but their share in the energy matrix was $30.9 \%$ in 2016 (Ministério de Minas e Energia 2017, 21). The most challenging is (iv) to increase the share of renewables other than hydropower in electricity supply to at least $23 \%$, as their share was 13.7\% in 2016 (Ministério de Minas e Energia 2017, 22); and (v) to achieve 10\% efficiency gains in the electricity sector.

The numbers show that, as much as before, Brazil is pledging to do what it has already started to do. If we focus on energy pledges alone, which are at the core of deep decarbonization, we can see that, except for the energy efficiency target - sadly ambitious, considering the poor levels found in Brazil -, the pledges create a buffer zone that allows fossil fuels to occupy a larger share in the Brazilian energy matrix, which is exactly what has been happening recently. By doing so, Brazil is not engaging in deep decarbonization, and is also reducing its possibility to do so in the near future. 


\section{Conclusion}

Our research shows that there is a significant gap between the normative goals established in climate negotiations and efforts to implement them. Although UNFCCC members have committed to limiting the long-term global average temperature to $2^{\circ} \mathrm{C}$, ideally $1.5^{\circ} \mathrm{C}$, the trajectory of major economies is still not aligned with the challenge. Deep decarbonization requires structural transformation, especially in energy systems, in order to reduce dependence on fossil fuel combustion. There has been some change in a few economies that are key to total global accountancy of GHG emissions, but (i) this change has been only marginal and (ii) drivers that explain it are more likely to be related to changes in their economic structure, concentrating economic output in less energy-intensive sectors, than to transformation of energy systems themselves.

In this scenario, Brazil starts comparatively ahead of its peers, given that the share of low carbon primary energy sources in the Brazilian energy matrix is substantially higher than global or G20 average. Yet, it is moving backwards. Brazilian GHG emissions have decreased only due to control in deforestation in the Amazon, not to change in activities that impact long-term economic development. Brazil is allowing increasingly larger shares of fossil fuels in its energy matrix. Increasing energy intensity of GDP is due to rising consumption and economic concentration in activities with low added value. In sum, Brazil is not engaging with deep decarbonization, instead it insists in a model that is incompatible with a low carbon future.

Although it might be argued that the consequences of the Brazilian trajectory for the global challenge is of lesser importance, given Brazil's smaller share in total global absolute and per capita GHG emissions and global TPES compared to other countries', it raises serious concern, for at least three reasons.

First, Brazil is among the countries that will be hit the hardest by climate change. Average temperature rise, changes in precipitation patterns and extreme weather events are predicted to be very severe in Brazil compared to global average, with daunting consequences for economic activity and livelihood in several areas of the country (Nobre et al. 2016; "Publicação mostra vulnerabilidades da agricultura às mudanças climáticas.” 2016). Second, being energy infrastructure a long-term asset, by allowing a larger share for fossil fuels in its energy matrix, Brazil is reducing both its current advantage in decarbonization and the opportunity to increase the role renewables in the future. Finally, given its environmental wealth, Brazil is an important player in global environmental governance. Although it does not have enough power assets to play a leading role in global governance (Viola et al. 2013; Viola and Franchini 2018), by joining a reformist coalition Brazil would substantially increase its role and impact in climate negotiations.

\section{Acknowledgements}

The author acknowledges the support from Coordenação de Aperfeiçoamento do Pessoal de Nivel Superior (CAPES) and the Fulbright Commission during her PhD, grants which made this research possible. 


\section{References}

Basso, L. Domestic determinants of international cooperation: an analysis of the intricate relationship between energy politics and climate change mitigation. PhD dissertation. Brasília, DF: Universidade de Brasília, 2018. Accessed December 28, 2018. http://repositorio.unb.br/handle/10482/32689? mode=full

Basso, L. and E. Viola. "From co-leader to loner: Brazilian wavering positions in climate change negotiations." In Brazil in the Anthropocene: Conflicts between predatory development and environmental policies, edited by L. -R. Issberner, and P. Lena, 193-217. New York, NY: Routledge, 2017.

Bataille, C., H. Waisman, M. Colombier, L. Segafredo, and J. Williams. "The Deep Decarbonization Pathways Project (DDPP): insights and emerging issues." Climate Policy 16, no. supl. 1 (2016): s1-s6. doi: https://doi.org/10.1080/14693062.2016.1179620

Costa, C. C., and H. L. Burnquist. "Impactos do controle do preço da gasolina sobre o etanol biocombustível no Brasil.” Estudos Econômicos 46, no. 4 (2016): 1003-1028. doi: https://doi.org/10.1590/0101-416146418cchb

Costa, J. O. P. "Normalização para inovação: o programa brasileiro de etiquetagem veicular (PBE-V)." In Políticas de inovação pelo lado da demanda, organized by A. R. Torquato, 121-177. Brasília, DF: IPEA, 2017.

Dias-Filho, M. B. Diagnóstico das Pastagens no Brasil. Documentos 402. Belém, PA: Embrapa, 2014.

Dutra, R. M., and A. S. Szklo. "A Energia Eólica no Brasil: PROINFA e o Novo Modelo do Setor Elétrico." paper presented at the 11th Congresso Brasileiro de Energia - CBE, v. II, Rio de Janeiro, RJ, August 2006.

Empresa de Pesquisa Energética - EPE. Balanço Energético Nacional, séries históricas completas, 1970-2016. Brasília, DF: EPE, 2018. Accessed September 1, 2018. https://ben.epe.gov. br/BENSeriesCompletas.aspx

Empresa de Pesquisa Energética - EPE. Plano Decenal de Expansão de Energia 2024. Brasília, DF: EPE, 2015.

Fankhauser, S., and F. Jotzo. "Economic growth and development with low-carbon energy." WIRES Climate Change 9, no. 495 (2018): 1-16. doi: https://doi.org/10.1002/wcc.495

Geels, F., B. K. Sovacool, T. Schwanen, and S. Sorrell. "Sociotechnical transitions for deep decarbonization.” Science Magazine 357, no. 6357 (2017): 1242-1244. doi: https://doi.org/10.1126/science.aao3760

Goertz, G., and J. Mahoney. A tale of two cultures: qualitative and quantitative research in the social sciences. Princeton, NJ: Princeton University Press, 2012. 
Held, D., E. -M. Nag, and C. Rogers. The Governance of Climate Change in Developing Countries. Paris: AFD's Research Department, 2012. Accessed April 15, 2016. https://www.afd.fr/en/governance-climate-change-developing-countries-reportinternational-and-domestic-climate-change-politics-china-brazil-ethiopia-and-tuvalu

Hira, A., and L. G. Oliveira. "No substitute for oil? How Brazil developed its ethanol industry." Energy Policy 37, no. 6 (2009): 2450-2456. doi: https://doi.org/10.1016/j.enpol.2009.02.037

Hochstetler, K., and G. Kotska. "Wind and solar power in Brazil and China: interests, state-business relations, and policy outcomes." Global Environmental Politics 15, no. 3 (2015): 74-94. doi: https://doi.org/10.1162/GLEP_a_00312

Hochstetler, K., and E. Viola. "Brazil and the politics of climate change: beyond the global commons." Environmental Politics 21, no. 5 (2012): 753-771. doi: https://doi.org/10.1080/09644016.2012.698884

Hochstetler, K. "Tracking presidents and policies: environmental politics from Lula to Dilma." Policy Studies 38, no. 3 (2017): 262-276. doi: https://doi.org/10.1080/01442872.2017.1290229

“Indicators:Agriculture, Forestry and Fishing's value added, \% of GDP; Industry's value added, \% of GDP.” World Bank Open Data, 2018. Accessed December 28, 2018. https://data.worldbank.org

Instituto Nacional de Pesquisas Espaciais - INPE. Taxas anuais de desmatamento na Amazônia Legal. Brasília, DF: INPE, n. d. Accessed Dec 1, 2017. http://www.obt.inpe.br/prodes/ dashboard/prodes-rates.html

Intergovernmental Panel on Climate Change - IPCC. Climate Change 2014: Mitigation of Climate Change. Paper presented at the Working Group III to the 5th Assessment Report of the Intergovernmental Panel on Climate Change. Cambridge: Cambridge University Press, 2014.

International Energy Agency - IEA. CO2 emissions from fuel combustion highlights 2018, Excel tables. Paris: IEA, 2017. Accessed November 15, 2018. https://www.iea.org/ publications/freepublications/publication/co2-emissions-from-fuel-combustionhighlights-2017.html retrieved.

Kasa, S. "The second-image reversed and climate policy: how international influences helped changing Brazil's positions on climate change." Sustainability 5, no. 3 (2013): 1049-1066. doi: https://doi.org/10.3390/su5031049

Machado, D. V. A Politica Externa do Etanol: estratégias do Estado Logístico para inserção internacional dos biocombustiveis brasileiros. PhD dissertation. Brasília, DF: Universidade de Brasília, 2014. Accessed June 15, 2015. http://www.repositorio.unb.br/ handle/10482/16989

Milner, H. Interests, institutions and information. Princeton, NJ: Princeton University Press, 1997. 
Ministério de Minas e Energia - MME. Resenha Energética Brasileira, exercício de 2016. Brasília, DF: MNE, 2017.

Nobre, C., J. A. Marengo, W. R. Soares, E. Assad, R. Shaeffer, F. R. Scarano, and S. S. Hacon. Riscos de mudanças climáticas no Brasil e limites à adaptação. Brasília, DF: Embaixada do Reino Unido, 2016. Accessed September 28, 2018. https://assets. publishing.service.gov.uk/government/uploads/system/uploads/attachment_data/ file/504489/Clima-Sumario-v3.pdf

Observatorio do Clima - OC. Sistema de Estimativa de Emissóes de Gases de Efeito Estufal System Gas Emissions Estimation (SEEG), version 6.0. Brasília, DF: Seeg Brasil, 2018 a. Accessed 2018. http://seeg.eco.br/en/

Observatorio do Clima - OC. Emissóes no Brasil caem 2,3\% em 2017. Brasília, DF: Seeg Brasil, 2018b. Accessed November 25, 2018. http://www.observatoriodoclima.eco.br/ emissoes-brasil-caem-23-em-2017/

Oliveira, A. "Political economy of the Brazilian power industry reform." In The political economy of power sector reform: the experience of five major developing countries, edited by D. G. Victor, and T. C. Heller, 31-75. Cambridge: Cambridge University Press, 2007.

"Publicação mostra vulnerabilidades da agricultura às mudanças climáticas." Embrapa Noticias, July 21, 2016. Accessed September 28, 2018. https://www.embrapa.br/buscade-noticias/-/noticia/14653225/publicacao-mostra-vulnerabilidades-da-agricultura-asmudancas-climaticas

Schaeffer, R., A. F. P. Lucena, R. Rathmann, A. Szklo, R. Soria, and M. Chavez-Rodriguez. Who Drives Climate-relevant Policies in Brazil? Evidence Report no. 132. Rio de Janeiro, RJ: Rising Powers in International Development, Institute of Development Studies, 2015. Accessed January 20, 2016. http://www.ids.ac.uk/publication/who-drives-climaterelevant-policies-in-brazil

Sustainable Development Solutions Network - SDSN, and Institute for Sustainable Development and International Relations - IDDRI. Pathways to Deep Decarbonization, 2015 Report. Paris, SDSN/IDDRI, 2015. Accessed June 3, 2016. http:// deepdecarbonization.org/ddpp-reports/

“Statistical Review of World Energy 2018, workbook." British Petroleum, June 2018. Accessed September 30, 2018. http://www.bp.com/statisticalreview

Victor, D. G., and T. C. Heller. The political economy of power sector reform: the experience of five major developing countries. Cambridge: Cambridge University Press, 2007.

Viola, E. "A política climática global e o Brasil: 2005-2010." Revista Tempo do Mundo 2, no. 2 (2010): 81-117.

Viola, E. "Brazil in the context of global governance politics and climate change, 1989-2003." Ambiente \& Sociedade 7, no. 1 (2004): 27-46. doi: https://doi.org/10.1590/S1414-753X2004000100003 
Viola, E. Brazilian climate policy since 2005: continuity, change and prospective. CEPS Working Paper nr. 373, 2013. Brussels: CEPS, 2013. Accessed September 14, 2015. https://www.ceps.eu/publications/brazilian-climate-policy-2005-continuity-changeand-prospective

Viola, E., and L. Basso. "Low carbon green economy: Brazilian policies and politics of energy, 2003-2014." In Handbook on Sustainability Transition and Sustainable Peace, edited by H. G. Brauch, U. O. Spring, J. Grin, and J. Scheffran, 811-830, The Hexagon Series on Human and Environmental Security and Peace, vol. 10. Cham: Springer, 2016. Viola, E., and M. Franchini. Brazil and climate change beyond the Amazon. New York, NY: Routledge, 2018.

Viola, E., and M. Franchini. "Climate politics in Brazil: public awareness, social transformations and emissions reduction." In Feeling the Heat: the politics of climate policy in rapidly industrializing countries, edited by I. Bailey, and H. Compston. London: Palgrave Macmillan, 2012.

Viola, E., M. Franchini, and T. L. Ribeiro. Sistema internacional de hegemoniaconservadora: governança global e democracia na era da crise climática. São Paulo, SP: Annablume, 2013. 